\title{
Theoretical and Conceptual Reflection Regarding Corporate Criminal Responsibilities Influencing the Formulation of Laws
}

\author{
Fitriani Rahmadia \\ Diponegoro University, Indonesia \\ rahma.diya@gmail.com
}

\begin{abstract}
In Indonesia, the development of the corporation as the subject to criminal acts takes place outside the Criminal Code, regulated in special legislation. While the Criminal Code itself still adheres to the subject of criminal acts in the form of people, the corporation (juridical person) appears as a subject that can commit a crime and should also be accountable in criminal law. However, this condition has not been realized concretely in our Criminal Code. The formulation policy regarding corporate criminal liability for victims of corporate crime that exists or is currently in force has not been able to realize the corporate criminal liability. Although there are sanctions that can be imposed on corporations, most of these provisions only protect potential victims and are not responsible for actual or real victims. In other words, the current formulation policy has not been able to ensnare and impose criminal sanctions on corporations who commit crimes, especially criminal sanctions which are oriented to the fulfillment or restoration of victims' rights in the form of compensation payments after the crime. This paper will discuss the position and the responsibility of the corporation as a subject of criminal law in Indonesia and analyze policy formulation of the Criminal Code and the draft of the Criminal Code that related to corporate responsibility as a legal subject.
\end{abstract}

KEYWORDS: Corporate Criminal Responsibilities, Criminal Law, Corporate Responsibility.

Copyright $\odot 2020$ by Author(s)

This work is licensed under a Creative Commons Attribution-ShareAlike 4.0 International License. All writings published in this journal are personal views of the authors and do not represent the views of this journal and the author's affiliated institutions.

\section{HOW TO CITE:}

Rahmadia, Fitriani. "Theoretical and Conceptual Reflection Regarding Corporate Criminal Responsibilities Influencing the Formulation of Laws" (2020) 7:1 Lentera Hukum 17-36. 


\section{INTRODUCTION}

Corporations in Dutch is "corporatie", in English is "corporation," and in German it called "corporation." All come from the word "corporation" in Latin, substantially derived from the word "corporare" used by people in the middle ages or afterward. In contrast, corporare itself comes from the word "corpus" in Indonesian means body or giving body or body, which means corporatio the result of bodywork. ${ }^{1}$ Both national and trans/multinational corporations have a significant and strategic role in modern life in the era of globalization. However, the essential and decisive role of corporations in a country's economic growth is often accompanied by violations of criminal law, ${ }^{2}$ accommodate the results of criminal acts, and as a means of committing crimes, and obtain profits from criminal acts through the collective decisions of its management. ${ }^{3}$

The term corporation is closely related to the term "legal entity," which is known in the field of civil law. ${ }^{4}$ However, in criminal law, the definition of a corporation turns out to be broader. because the corporation is meant to be not limited to only "legal entities $^{5}$ The corporation is an abstraction; it no longer has its mind compared to its body, the will and directed will have to be consistently seen in something which for a particular purpose may be called an agent or a representative, but who directs the mind and spirit of the corporation consist of the ego and the center of the corporation itself. ${ }^{6}$

Corporations can increase state wealth and labor, but the revolutionary economic and political structure has grown a tremendous corporate power so that the state is too dependent on corporations so that the state can be dictated according to its interests. Large companies have not only such great wealth but also have social and political strength in such a way that the operations or activities of these companies significantly affect the lives of everyone from birth to death. So that the Corporation has an important role and high power in carrying out its activities, although it often performs activities that are contrary to applicable legal provisions. ${ }^{7}$

Since the 1970s, the world's attention has focused on issues that are closely related to crime that is directly related to development programs. The UN Congresses on The Prevention of Crime and The Treatment of Offenders consistently highlight the forms and dimensions of development (crimes against development), crimes against social welfare, and crimes against social welfare (crimes against the welfare) quality of

1 Yudi Krismen, "Pertanggungjawaban Pidana Korporasi dalam Kejahatan Ekonomi” (2014) 0403 June 2014 (1) 140.

2 Levina Yustitianingtyas, "Pertanggungjawaban Pidana oleh Korporasi dalam Tindakan Pelanggaran HAM di Indonesia" (2016) 7:1 Novelty 25.

3 Budi Suhariyanto, "Urgensi Pemidanaan terhadap Pengendali Korporasi yang Tidak Tercantum dalam Kepengurusan" (2017) 103 Yudisial 240.

4 Kristian, "Urgensi Pertanggungjawaban Pidana Korporasi" (2014) Year-43:Hukum dan Pembangunan Oct-Dec 550.

5." Dwidja Priyanto, "Reorientasi dan Reformulasi Sistem Pertanggungjawaban Pidana Korporasi dalam Kebijakan Kriminal dan Kebijakan Hukum Pidana" (2007) 9:3 Syiar Hukum 205.

6 Muchammad Chasani, "Corporate Criminal Liability In Indonesia On The Perspective Of Comparison" (2017) II:2 IJCLS 149 at 146.

7 Endi Arofa, "Korporasi Sebagai Subjek Dan Bentuk Pemidanaannya Dalam Tindak Pidana Korupsi" (2018) 5:1 Journal Surya Kencana 2449. 
life). ${ }^{8}$ Included in such crimes are "economic crimes," which are often referred to by various terms, including "economic crimes," "crimes as a business," "business crimes," and "abuse of economic power." So it can be said that economic crime is a prominent feature of crime against the development of the community of nations in the world, both in societies that are already advanced/modern or that are undergoing development towards modernization.

The problem of corporation as a subject of criminal law cannot be separated from aspects of civil law. In private law, individuals are not the only legal subjects. It is since there are still other legal subjects who have rights and can carry out legal actions the same as individuals. This view is different from the Criminal Code, which only knows individuals as legal subjects.

Emergency Law Number 7 of 1955 concerning Investigation, Prosecution, and Judgment of Economic Crimes states firmly that the subjects of criminal law are persons and legal entities of companies, unions, and foundations; All types of business forms refer to 'corporation ${ }^{9}$ It is different from the Criminal Code, which states that the subjects of criminal law are individuals. In reality, White Collar Crimes often occur in the form of corporate crime, banking crime, and corruption. Corporate crime is not chosen by an evil impulse, but by something that is not regarded morally. These crimes seriously hurt people's feelings about justice, honesty, solidarity, and social responsibility. In terms of a corporation is a combination of people in legal associations act together as separate legal subjects. Corporations are legal entities whose members have their rights and obligations separate from the rights and obligations of each member.

So that the discussion about the corporation is already familiar to us, even lately, we often hear about corporate strategy, whether it is mergers, acquisitions, consolidation, tax planning, and others. Corporations contribute a lot to the development of a country, especially in the economic field, for example, state revenues in the form of taxes and foreign exchange, so that the impact of the corporation looks very positive. However, on the other hand, corporations also often create negative impacts, such as pollution, depletion of natural resources, fraudulent competition, tax manipulation, exploitation of labor, produce products that endanger the user, and fraud against consumers. Corporations can increase state wealth and labor, but the revolutionary economic and political structure has grown a tremendous corporate power so that the state is too dependent on corporations so that the state can be dictated according to its interests. ${ }^{10}$ Large companies have not only such great wealth but also have social and political strength in such a way that the operations or activities of these companies significantly affect the lives of everyone from birth to death. The work-life and health and safety of the majority of the population are controlled either directly or indirectly by these large companies. It has been proven that multinational

8 United Nations, "Guiding Principles for Crime Prevention and Criminal Justice in the Context of Development and a New International Economic Order" 4.

9 Priyanto, supra note 5.

10 Arofa, supra note 7. 
companies have exercised political influence both on the government at home and abroad where the company operates.

The losses incurred by corporate crime can be physical, economic, and social costs. Labor accidents are a physical consequence. The case of poisoned biscuits that cause casualties is an example of the results of the production of a corporation that is not safe for consumers, which is often called corporate negligence. The economic consequences are no doubt, considering that profit is the primary motivation for the occurrence of corporate crime. In contrast, the most threatening and frightening of those considered social losses arising from corporate crime is the damaging impact on the moral standards of the business community. The influence of the extraordinary growth of assets sold by giant corporations and conglomerates that reach millions or even billions of dollars makes the corporation has extraordinary economic, social, and political power. ${ }^{11}$ It asserts that these corporate giants can control the economic, social, and political life of the State. Corporate power in the language of the economy is exercised through decisions in investment, pricing, location, research and design of products, but also has social and political consequences such as employment, issues relating to the lives of local communities, and the quality of human life in general. ${ }^{12}$

The study has two main objectives. First, this study is to discuss the corporation as a subject of criminal law in Indonesia, following its position and responsibility. Second, this study is to analyze the policy formulation of the Criminal Code and the draft of the Criminal Code related to corporate responsibility as a legal subject in Indonesia. So as the development of science, including criminal law, it was supposed necessary to ensnare corporations as well as subjects of criminal law, given the enormous contribution of corporations as pioneers of funds for the state. Almost all aspects of community life involve the corporation in it. It can be seen that the corporation is engaged in various fields such as agriculture, banking, entertainment, and others, which involve a significant amount of money circulation. It is an undeniable fact that the role of corporations today is critical in people's lives. Their role dominates daily life, let alone increased privatization. It is no longer a country that provides needs, but corporations. The corporation has provided all the needs of the community from birth to death.

\section{THE POSITION AND THE RESPONSIBILITY OF THE CORPORATION AS A SUBJECT OF CRIMINAL LAW}

Corporate crime, which is usually in the form of white-collar crime, is generally committed by a company or legal entity engaged in the business field with a variety of actions that are contrary to applicable criminal law. Based on experience from various developed countries, it can be stated that the identification of corporate crimes can include criminal acts such as violations of monopoly laws, computer fraud, payment of

\footnotetext{
$11 \quad$ Ibid.

12 Ibid at 450 .
} 
taxes and excise, violations of price provisions, production of goods that endanger health, corruption, bribery, administrative violations, labor, and environmental pollution. In Indonesia, the regulation of Corporations as legal subjects is regulated in Article 1 number 13 and Article 70 of Law Number 5 of 1997 concerning Psychotropics, Article 1 paragraph (21), Article 75 letter b and Article 130 of Law Number 35 of 2009 concerning Narcotics, Article 1 number 1 and Article 20 of Law Number 31 of 1999 concerning Eradication of Corruption, Article 78 paragraph (14) of Law Number 41 of 1999 concerning Forestry, Articles 116, 117, 119 of Law Number 32 of 2009 concerning Environmental Protection and Management, Article 6 of Law Number 8 of 2010 concerning Prevention and Eradication of Money Laundering Crimes.

Victims of corporate crime are broader in scope than victims of crime in general (conventional crime) both in terms of the number of victims and losses incurred. Hence, victims of corporate crime need special attention in preventing and overcoming corporate crime in this case in the form of accountability for corporate criminal acts against victims of corporate crime. It is essential to ensnare corporations for crimes committed through the laws and regulations governing corporate responsibility, but equally important is to provide protection and justice to victims of corporate crime. However, in determining the scope of corporate crime itself can be explained by Steven Box, where the scope of corporate crime includes: Crimes for corporation is a violation of law committed by a corporation to achieve the corporation's goal of obtaining profit; Criminal corporation, which is a corporation whose sole purpose is to commit a crime; and Crime against corporations, i.e., crimes against corporations such as theft or embezzlement of corporations, in this case, the victims are corporations.

Based on the scope provided by Steven Box above, it can be determined that what is meant by corporate crime in this study is a corporate crime in the form of crimes for a corporation, which is a crime committed by a corporation in the context of seeking profit. Regarding the separation of corporate and managerial criminal responsibility (human subject) when a crime occurs within the corporation. This situation results in very few legal cases that make corporations can be prosecuted for behavior that is contrary to legal provisions. These behaviors contain criminal sanctions, and there is a tendency to see corporations and personal directing minds of corporations as the same legal subjects so that they can be exchanged with each other (interchangeable) in terms of prosecution and imposing criminal sanctions. ${ }^{13}$

Although in principle, corporations can be held accountable by individuals, there are some exceptions, namely: ${ }^{14}$ in cases which by nature cannot be done by corporations, for example, bigamy, rape, perjury, and in cases where the only crime that can be imposed may not be imposed on the corporation, for example, imprisonment and capital punishment. The Indonesian Criminal Code (KUHP) currently in force is a

13 Budi Suhariyanto, "The Role Of Regulation Of The Supreme Court Number 13 Year 2016 In Overcoming The Obstacles Of Corporation Criminal Infringement" (2018) Peneliti Huk MA 103 at 108.

14 Sunarto, "Pertanggungjawaban Pidana Korporasi Dalam Tindak Pidana Korupsi" UNTAG Semarang 48 at 54 . 
Dutch legal product that is enforced based on the principle of concordance in the Dutch East Indies. The subject of a crime known in the Criminal Code is a person. In other words, only humans can commit crimes, and only humans can be prosecuted and burdened with criminal liability. The Criminal Code does not recognize corporations as subjects of criminal law. Based on Article 59 of the Criminal Code, whereby if a corporation commits a criminal offense, criminal liability is imposed on the corporate management if the corporate administrator commits a criminal offense, representing or on behalf of the corporation. In its development, the corporation (juridical person) appears as a subject that can commit a crime and should also be accountable in criminal law. Unfortunately, this condition has not been realized concretely in our Criminal Code.

The grouping of laws that declare corporations as subjects and can be accounted for include: ${ }^{15}$ the first one is the regulation in the Criminal Act, and they were: Article 1 number 1 of Law Number 31 of 1999 jo. Law Number 20 of 2001 concerning Eradication of Corruption; If it is carried out by "corporation" the meaning is that a corporation is a collection of people and/or assets that are organized either as a legal entity or not a legal entity, Article 1 number 24 of Law Number 32 Year 2009 concerning the Environment states that what is meant by people is individuals and/or groups of people and/or legal entities, Act Number 22 of 1997 (Narcotics; replaces Act Number 9 of 1976), Law Number 15 of 2002 (Money Laundering), Government Regulation Number 2 Year 2002 Jo. Law Number 15 Year 2003 (Eradication of Terrorism Crimes), and Law Number 21 of 2007 (Trafficking in Persons). Then the second one is the regulation in Administrative Law, and they were: Law Number 7 Drt. 1955 (Economic Criminal Act) - Deprecated, Law Number 11 Pnps. 1963 (Subversion; revoked), Law Number 5 of 1984 (Industry), Law Number 6 of 1984 (Post), and Law Number 9 of 1985 (Fisheries). However, to determine the existence of aspects of criminal law must be seen with parameters that contain nuances of criminal law such as deceit, manipulation, misrepresentation, concealment of facts, breach of trust (breach of facts), reason subterfuge, or circumvention of rules (illegal circumvention). ${ }^{16}$

After knowing the position of the corporation, we must know the criminal liability that can be imposed on the corporation. Van Bemmelen, given the intentions of the corporation, argues that the shared knowledge of most members of the board of directors can be regarded as intentional of the corporation, if possible, as a conditional intentional. ${ }^{17}$ Regarding this, it was first developed in countries that adopted the common law system, such as the United Kingdom and the United States. Its development was a result of the industrial revolution that began in that country. There are several theories of corporate criminal liability on which to base criminal liability on

15 Muladi \& Diah, Pertanggungjawaban Pidana Korporasi/Corporate Criminal Responsibility, 2d ed (Bandung: PT. Alumni, 2015).

16 Nyoman Serikat Putra, Hukum dan Hukum Pidana di Bidang Ekonomi (Semarang: Badan Penerbit Universitas Diponegoro, 2018).

17 JM Van Bemmelen, Hukum Pidana I: Hukum Pidana Material Bagian Umum (Bandung: Binacipta, 1986) at 237. 
corporations. The theory of corporate criminal liability includes the theory of identification (identification theory), vicarious liability theory, and the theory of absolute liability (strict liability). Strict liability is: The maker can already be convicted if he has committed an act as formulated in the law without seeing how his inner attitude. ${ }^{18}$ Vicarious liability is often interpreted to be "liable according to someone's law for wrongdoing done by others. ${ }^{19}$

Identification theory is one of the theories of corporate criminal liability. Criminal liability for the corporation must be identified in advance who committed the crime. If the person committing the crime is a "directing mind" or a person authorized to act on behalf of the corporation, then corporations can be liable for criminal liability. Identification theory is one of the theories that justify corporate responsibility in criminal law. This theory states that the actions or wishes of the director are also the actions or wills of the corporation (the act and state of mind of the person are the acts and state of mind of the corporation). ${ }^{20}$ Peter Gillies stated that: "the law now recognizes that the company can incur criminal liability, although not for all crimes." So not all criminal acts can be committed by corporations and can be accounted for by corporations. ${ }^{21}$

The theory of vicarious liability is a theory of corporate criminal liability in which a person, in this case, the corporation, is responsible for the mistakes of others. This theory refers to the employment principle, where the employer is responsible for the actions of his workers in the scope of his duties and work. The theory of absolute liability is the most practical theory of corporate criminal liability. Corporate criminal liability is imposed on the person who commits the criminal act without the need to prove whether there is an element of error. Several existing theories of corporate criminal liability are expected to provide a legal basis for assigning corporate criminal liability to victims of corporate crime. It is the main problem which in the future is expected to be accommodated so that criminal law policies relating to corporate crime can be effectively operationalized while still paying attention to and adhering to the objectives of social policy, namely the protection and welfare of the community.

The reasons for imposing upon corporations criminal responsibility for their agents' acts are the same reasons which justify treating the same acts as criminal in the individual actors. Whatever social purpose (if any) tends to be served by punishing or threatening to punish the individual who does a given act, also tends to be served by punishing or threatening to punish the corporation in the course of whose business he does it. ${ }^{22}$ The argument against corporate criminal responsibility that the corporation can not itself be "guilty" and therefore should not be punished, rests on the tacit assumption that the aim of criminal law is retributive or retaliative, which is to say

\footnotetext{
18 Sunarto, supra note 14 at 53.

19 Ibid.

20 Richard Card, "Reformasi Pertanggungjawaban Pidana” (1999) 6:1l Jurnal Ilmu Hukum 29.

Sunarto, supra note 14 at 54.

22 Henry W Edgerton, "Corporate Criminale Responsibility” 36:6 Yale Law Journal 882.
} 
vindictive or vengeful; consists, in other words, in the pleasure which some persons derive from the infliction of pain upon those whom they conceive to deserve it.

After discussing the arrangement of corporations as subjects of criminal law, the next arrangement is how to regulate criminal procedural law in order to ensnare corporations as perpetrators of criminal acts. Law Number 31 of 1999 has generally regulated criminal procedural law to ensnare corporations. However, the arrangements are still limited as regulated in Article 20, as follows: 1) If a criminal act of corruption is carried out by or on behalf of a corporation, criminal charges and conviction can be committed against the corporation and or its management, 2) A criminal act of Corruption is carried out by a corporation if the crime is committed by people both based on work relationships or based on other relationships, acting within the corporate environment both individually and jointly, 3) If a criminal complaint is made against a corporation, the corporation is represented by the management, 4) Other people may represent management representing companies, as reffered to number 3,5 ) The judge can order that the management of the corporation confronts himself in court and may also order that the administrator be brought to a court hearing, 6) In the event that a criminal complaint is made against a corporation, the summons to appear and the submission of the summons shall be conveyed to the board of management of the board of residence or at the place of office management, 7) The major crimes that can be imposed on corporations are only criminal fines, with a maximum criminal provision plus $1 / 3$ (one third).

Regarding who can be held accountable for crimes committed by corporations is very important, because this is very closely related to criminal liability for crimes committed by corporations. If it can be identified who is responsible for crimes committed by corporations, then prosecution and criminal prosecution can be carried out to those who can be accounted for. In the Economic Criminal Act especially in Article 15 paragraph (1) it has been determined that if a corporation commits a criminal offense, then the corporation that can be prosecuted and convicted and disciplinary action is the corporation itself, which gives the order to commit a criminal offense, or second- both (the corporation and the one giving the orders). Law Number 23 of 1997 concerning Environmental Management in Article 46 paragraph (1) and (2) broadly stipulates that those liable for criminal liability are: (1) corporation or legal entity, corporation, union, foundation or other organization; (2) those who give orders to commit a crime; (3) or both, namely the corporation and those who give orders to commit a crime.

In Indonesia, the development of corporations as subject to criminal offenses takes place outside the Criminal Code, in specific laws. While the Criminal Code itself still adheres to the subject of criminal acts in the form of people. There are similarities between the last two opinions, which suggest that the notion of a corporation as a legal subject in criminal law is broader than the notion of a corporation as a legal subject in civil law. However, the definition of corporation in criminal law has a broader understanding when compared to the notion of a corporation in civil law, which is 
limited only to legal entities. ${ }^{23}$ It refers to the arrangement of corporations as subject to criminal acts in special statutory regulations outside the Criminal Code. Corporate arrangements as subject to criminal offenses are contained in special legislation outside the Criminal Code, including: Law Number 7 of 1955 concerning Economic Crimes, Law Number 5 of 1984 concerning Industry, Law Number 6 of 1984 concerning Postal, Law Number 9 of 1985 Concerning Fisheries as amended by Act Number 31 of 2004, Act Number 7 of 1992 concerning Banking as amended by Act Number 10 of 1998, Law Number 8 of 1995 concerning Capital Markets, Law Number 5 of 1997 concerning Psychotropics, Law Number 22 Year 1997 concerning Narcotics, Law Number 23 of 1997 concerning Environmental Management, Law Number 5 of 1999 concerning the Prohibition of Monopolistic Practices and Unfair Business Competition, Law Number 8 of 1999 concerning Consumer Protection, Law Number 31 of 1999 concerning Eradication of Corruption Crimes as amended by Law Number 20 of 2001, Law Number 21 of 2001 concerning Oil and Gas, Law Number 8 of 2010 concerning Prevention and Eradication of Money Laundering Crimes. From the various regulations above that formulate corporations as subject to criminal acts in legislation, it can be seen that the regulation of corporations as subjects of crime is included in special laws outside the Criminal Code. In addition, these laws and regulations indicate that the notion of a corporation in the field of criminal law is broader than the notion of a corporation in the field of civil law.

Some laws state that when a corporation conducts it, the corporation that is responsible and sentenced to criminal (such as Law Number 20 Year 2011 on Flats), some other laws specify that the corporation and its management both individually and together can be prosecuted and convicted (such as Law Number 7 of 1955 concerning Economic Crimes). ${ }^{24}$ The Economic Crime Act is the adoption of the Wet op de Economische Delicten in the Netherlands in 1950, which introduced the corporate position first as a criminal law subject. ${ }^{25}$ This concept was then incorporated by the Netherlands into the Wetboek van Straftrecht Amendment in 1976, as contained in Article 51 Wetboek van Strafrecht. ${ }^{26}$ With the enactment of the amendments to Wetboek van Straftrecht (WvS), the provisions regarding corporations as subject to criminal law in Article 15 of the Wet de op Economiche Delicten are abolished. ${ }^{27}$ In Indonesia, although the current Penal Code does not accommodate corporations is subject to criminal law. However, the draft of the Criminal Code has accommodated corporations as subjects of criminal law.

\footnotetext{
23 Aulia Ali Reza, "Pertanggungjawaban Korporasi Dalam Rancangan Kitab Undang-Undang Hukum Pidana” (2015) ICJR 4.

24 Suhariyanto, supra note 13 at 108.

25 Mardjono Reksodiputro, Tindak Pidana Korporasi dan Pertanggungjawabanya (Perubahan Wajah Pelaku Kejahatan di Indonesia) (Yogyakarta: FH UGM, 2014).

26 Van Bemmelen, supra note 17.

27 Ibid.
} 
When a corporation is held criminally liable for a criminal offense, it is generally known that three corporate criminal liability systems are as follows: ${ }^{28}$ the management of the corporation as the actor, responsible management, Corporations as actors, responsible executives, and the corporation as the actor and the responsible. After an analysis of the statutory regulations outside the Criminal Code, the results obtained related to the type of sanctions that can be imposed on corporations for the crimes they have committed. ${ }^{29}$ These sanctions are in the form of criminal fines, additional crimes, and disciplinary actions. The three sanctions are types of sanctions that can be threatened by the corporation in relation to the nature of the corporation as a subject of a crime that is different from the subject of a criminal act in the form of a human or an individual person. There are criminal sanctions applied to criminal subjects in the form of people who cannot be applied to corporations, such as prisons or confinement.

As for the sanctions or laws that can be imposed on the Corporation according to the guidelines outlined in Article 25 paragraph (1) of the Supreme Court Regulation Number 13 of 2016 are the principal and/or additional crimes. The major crime that can be imposed on a Corporation is a criminal fine. Whereas the additional penalties imposed on Corporations under other laws and regulations, namely Article 10 of the Criminal Code and other types of criminal provisions scattered in other laws as lex specialis of the Criminal Code, which is legi generali. ${ }^{30}$

Overall, the Criminal Code concept currently does not classify or explicitly regulate the types of crimes that can be applied to criminal subjects in the form of people and other types of crimes that can be applied to non-person (corporate) criminal subjects. It is essential to differentiate the types of crimes that can be applied to people and the types of crimes that can be applied to corporations so that corporations that commit crimes can be subject to criminal offenses following their capacity as criminal subjects rather than people. So, there must be an understanding that in criminal law, there is the principle of culpability, so it must be proven that a person can be convicted if he is proven guilty. It means that criminal sanctions cannot be automatically transferred from corporate crime to personal crime. In general, it should not only be charged with corporations but also individuals who are responsible for related criminal events. Muladi adds ineffective law enforcement systems, very mild criminal offenses, lack of crime and stigmatization, deterrence, lack of social reaction through mass media, and extensive opportunities also much encourage corporate crime. ${ }^{31}$

The handling of corporate criminal acts in Indonesia faces constraints due to unclear arrangements for handling corporate crimes. In order to overcome the imperfections of the arrangement, at the end of 2016, on December 29, the Supreme Court issued the Supreme Court Regulation Number 13 of 2016 concerning Procedures

28 Chasani, supra note 6 at 148.

29 Chasani, supra note 6.

30 Peraturan Mahkamah Agung Republik Indonesia Nomor 13 Tahun 2016 Tentang Tata Cara Penanganan Perkara Tindak Pidana Oleh Korporasi.

31 Muladi \& Dwija Priyatna, Pertanggungjawaban Korporasi Dalam Hukum Pidana (Bandung: Penerbit Sekolah Tinggi Hukum Bandung, 1991). 
for Handling Criminal Cases by Corporations. The difference in interpretation and doubt of law enforcement and judges must be sought for a solution. Based on this, the Supreme Court deems it necessary to issue guidelines for corporate punishment for law enforcement officials and judges. The Supreme Court Regulation Number 13 of 2016 was issued with the consideration that many laws in Indonesia regulating corporations as subjects of criminal acts can be held accountable, but cases with corporate legal subjects submitted in criminal proceedings are still minimal. That is because the procedures and procedures for corporate investigation as a criminal offense are still unclear. The Supreme Court Regulation Number 13 of 2016 consideration is in sync with the background of the issuance of the Attorney General's Regulation (PERJA) Number PER-028/A/JA/10/2014 dated October 1, 2014, concerning Guidelines for Handling Criminal Cases with Corporate Legal Subjects, namely disclosure of cases involving corporations as subjects of criminal offenses still challenging to express given the complexity of the complexity.

Article 79 of the Law on the Supreme Court (PERMA) provides a legal basis that if in the course of the trial there is a shortage of legal vacuum in a matter, the Supreme Court has the authority to issue regulations to fill these deficiencies or vacancies. Then, the Supreme Court Regulation Number 13 of 2016 can be used as a guideline for Law Enforcement to overcome the technical obstacles of corporate criminal procedural law, even though the Supreme Court Regulation Number 13 of 2016 has limitations, so it is necessary to update the corporate criminal procedure law in the draft of the Criminal Procedure Code (RUU KUHAP). However, the Supreme Court Regulation Number 13 of 2016 still has some shortcomings. First, the Supreme Court Regulation Number 13 of 2016 is still a transitional nature to fill the legal vacuum. Further arrangements should be in the Criminal Code. However, the draft of the Penal Code is still being discussed. Second, the contents of the Supreme Court Regulation Number 13 of 2016 are considered to be colliding with similar internal rules in other institutions. For example, the Indonesian Attorney General's Office has a Regulation of the Attorney General Number 28 of 2014 concerning Guidelines for Handling Criminal Cases with Corporate Legal Subjects. Third, the Supreme Court Regulation Number 13 of 2016 only regulates formalprocedural issues, not regulating substantial matters, like withdrawing corporate criminal liability, when an action can be charged to the corporation, and when an action cannot be charged to the corporation. Fourth, the Supreme Court Regulation Number 13 of 2016 has not touched corporations in the form of non-legal entities. The Supreme Court Regulation Number 13 of 2016 is also said not to explain any corporation which is a legal entity and anything corporation that is not a legal entity as well as how is the arrangement between one and the other. Fifth, the limitation in determining the actions of someone who does not have the authority to make decisions but can control or influence corporate policy or in the Supreme Court Regulation Number 13 of 2016 is called "Management." This limit is considered still unclear. Sixth, there is no explanation of the difference between corporate group responsibility and the inclusion of criminal acts. Seventh, sanctions given are still limited to fines. Sanctions 
should be supplemented by the revocation of business licenses, legal entity status, seizure of profits, closure of part or all of a company, repairs as a result of a criminal offense, or putting the company under a maximum of three years. Eighth, the Supreme Court Regulation Number 13 of 2016 does not regulate significant differences in establishing a corporation or management as a suspect/defendant. ${ }^{32}$ According to the Supreme Court Regulation Number 13 of 2016, in the case of a criminal offense committed by a corporation involving the parent company and/or a subsidiary of a subsidiary and/or corporation that have a relationship can be criminally liable following their respective roles. ${ }^{33}$

\section{FORMULATION POLICY REGARDING THE CORPORATION AS A LEGAL SUBJECT}

Formulation policy is a policy in formulating something in the form of legislation. The formulation policy, according to Barda Nawawi Arief, is a plan or program from the legislators regarding what will be settled in facing certain problems and how to do or do something that has been planned or programmed. ${ }^{34}$ The regulation of corporate criminal liability in the Indonesian criminal justice system is a new and still debatable issue. It is said that because the Criminal Code is not recognized and regulated explicitly about the corporation as a subject of criminal law. It is a natural thing since the WvS Criminal Code still adheres to the principle of "societas delinquere non potest" or "non-potest university delinquere", is legal entities can not commit a crime..$^{35}$ Thus, it can be said that the regulation of corporate criminal responsibility in the legal system in Indonesia is expressly only regulated in special criminal legislation because the Criminal Code of WvS still using the principle of "societas delinquere nonpotest" so it is not possible to enforce corporate criminal liability in it. ${ }^{36}$

In later developments, difficulties arise in practice because, in various specific criminal acts, developments arise, which assumes that criminal acts can also be committed by corporations, bearing in mind the quality of conditions that are only owned by the legal entity or corporation. Finally, based on Article 91 of the Dutch Penal Code, or Article 103 of the Indonesian Penal Code, it is permissible for regulations outside the Penal Code to deviate from the General Provisions of Book I of the Criminal Code. $^{37}$

It is not enough just because of proven actions a person is criminal, but there must be a mistake. An adagium states "actus non facit reum, nisi mens sit rea" (that means

32 Taufik Rahardian, "Kelemahan 8 PERMA Pidana Korporasi", online: Kumparan News 〈https://kumparan.com/@kumparannews/8-kekurangan-perma-pidana-korporasi〉.

33 Suhariyanto, supra note 13 at 112.

34 Barda Nawawi Arief, Kebijakan Legeslatif Dalam Penenggulangan Kejahatan Dengan Pidana Penjara (Dissertation, Diponegoro University, 1994) [unpublished].

35 Chasani, supra note 6.

36 Sunarto, supra note 14.

37 Ibid. 
the act does not make a person guilty unless there is a wrong inner attitude). ${ }^{38}$ It confirms that a statement against a person has violated criminal law and is subject to sanctions must meet two underlying conditions: First, the person is legally proven and convincing that he is really committed a crime, and Second when the person commits a criminal offense must prove that he is a person who can be held criminally responsible. ${ }^{39}$

Emergency Law Number 7 of 1955 is seen as a particular crime, in which it has its specificity both formally and materially that deviates from criminal law and criminal procedure law in general..$^{40}$ Even the current Penal Code does not yet regulate corporate criminal liability in the sense that it does not recognize the corporation as the subject of a criminal offense. However, several special laws outside the Criminal Code already recognize the corporation as a subject of criminal offenses other than people. Several laws outside the Criminal Code that have governed corporations as subject to criminal offenses include Emergency Law Number 17 of 1951 concerning Stockpiling of Goods, which is the first positive law that uses the principle that corporations can become perpetrators of crime. Emergency Law Number 7 of 1955 concerning the Investigation, Prosecution, and Judgment of Economic Crimes states firmly that the subjects of criminal law are persons and legal entities of companies, unions, and foundations; ${ }^{41}$ All types of business forms refer to 'corporation.' It is different from the Criminal Code, which states that the subjects of criminal law are individuals. In reality, White Collar Crimes often occur in the form of corporate crime, banking crime, and corruption. Corporate crime is not chosen by an evil impulse, but by something that is not felt morally. These crimes seriously hurt people's feelings about justice, honesty, solidarity, and social responsibility. In terms of a corporation, it is a combination of people in legal associations act together as separate legal subjects. Corporations are legal entities whose members have their rights and obligations separate from the rights and obligations of each member.

Corporations are included as "legal personality" in the form of besloten vennootschap (limited liability company) and or naamloze vennootschap (Limited Liability Company (PT Tbk) mentioned in Dutch Civil Code Article 2. The Dutch Supreme Court then clearly mentions four situations in which the behavior, in principle, can be said to be within the scope of the corporation, they were: ${ }^{42}$ Where the case concerns the act or omission of a person who works for the enterprise, within or outside the formal employment contract; Behavior under the company's 'normal business' day to day; Corporations

38 Teguh Prasetyo \& Abdul Halim Barkatullah, Politik Hukum Pidana, Ctk. Pertama (Yogyakarta: Pustaka Pelajar, 2005).

39 Abdul Kholiq, Hukum Pidana (Yogyakarta: Fakultas Hukum Universitas Islam Indonesia, 2002).

40 Patricia Rinwigati, "Tindak Pidana Ekonomi Dalam RKUHP: Quo Vadis?" (2016) Parliamentary Brief Aliansi Nas Reformasi KUHP (6) 5.

41 Kartin S Hulukati, Kebijakan Formulasi Tindak Pidana Ekonomi Dengan Undang-Undang Nomor 7/DRT/1955 (Semarang: Badan Penerbit Universitas Diponegoro, 2003).

42 BF Keulen \& E Gritter, "Corporate Criminal Liability in the Netherlands" 14:3 Electronic Journal Comparative Law 5. 
benefit from the behavior; The course of action is the 'gift' of the corporation, and the corporation has approved it.

For the various impacts of their crimes, corporations are then criminalized. Corporations are made as subjects of criminal law because they are considered capable of carrying out legal actions or actions, including behavior that violates or is against the law. ${ }^{43}$ Consequences of a corporation as a subject of criminal law mean that a corporation can commit a crime or what is done can fulfill the objective element of the offense, ${ }^{44}$ which can then be prosecuted for criminal liability. Corporate responsibility based on the existence of a corporation is not formed without a goal, and achieving the objectives of the corporation is always realized through natural human actions. Therefore, the ability to be responsible for those who do for and on behalf of the corporation is transferred to the ability to be responsible for the corporation as the subject of criminal acts. ${ }^{45}$ Even though many laws in Indonesia have placed corporations as the subject of criminal acts that can be held accountable, cases with corporate legal subjects submitted in criminal proceedings are still very limited. One reason is the procedure and procedures for examining corporations as perpetrators of crime are still unclear, giving rise to an absence of procedural law regarding procedures for handling corporate criminal offenses. ${ }^{46}$ The impact of the legal vacuum mentioned above causes law enforcement officers to still unable to examine the corporation as a suspect/defendant. The next result is that the handling of corporate criminal acts has not been effective.

The corporation may also be held responsible in criminal law for the act of a person in the case of possible vicarious liability, so in the corporation's position as an employer. This vicarious responsibility must be differentiated from liability based on the principle of identification. Also, corporations can be responsible for the actions of corporate leadership people who decide the company's business. ${ }^{47}$

Meanwhile, special criminal law is often interpreted as criminal provisions governing specifically that deviate from general criminal provisions. This deviation aspect is essential in particular crime because if there are no deviations, it cannot be called special criminal law. In material law, regulation can be in the form of criminal offenses and violations, expansion of the specified territorial, legal, or criminal principles based on losses, financial, and economic conditions of the country. In formal law, deviations can be in the form of investigations conducted by certain institutions,

43 Tjandra Sridjaja Pradjonggo, "Alternatif Sanksi Pidana dalam Kejahatan Korporasi" (2010) 80:2 Journal Yustisia 70.

44 M Haryanto, "Pertanggungjawaban Pidana Korporasi dan Individualisasi Pidana" (2012) 2 Journal Refleksi Hukum 203.

45 Ridwan Rangkuti, "Pertanggungjawaban Korporasi terhadap Tindak Pidana Lingkungan Hidup Menurut Undang-Undang Nomor 23 Tahun 1997” (2014) l:3 Journal Yustisia 263.

46 Budi Suhariyanto, "The Role Of Regulation Of The Supreme Court Number 13 Year 2016 In Overcoming The Obstacles Of Corporation Criminal Infringement" (2018) Penelitian Hukum MA 103.

47 Chasani, supra note 6 at 151. 
prioritizing certain crimes from the case other crimes, the existence of arrangements regarding civil lawsuits, and so on. ${ }^{48}$

Duplication of the norms of the rules in the Criminal Code with norms outside the Criminal Code, unstructured and systematic criminal prosecution, and too many laws that make special provisions and the frequent changes in criminal law norms are significant challenges faced by experts and legal practice. ${ }^{49}$ The patchwork of a quick solutions system has been criticized by various criminal experts as' unsystematic, inconsistent, juridical, and even undermining wild plants/buildings, shredding the primary building system. ${ }^{50}$

The criminal liability system for environmental offenders cannot be separated from the legislative policies outlined in environmental legislation. ${ }^{51}$ The law was then followed by other laws such as Emergency Law Number 7 of 1955 concerning Economic Crimes, Law Number 5 of 1984 concerning Industry, Law Number 6 of 1984 concerning Postal, Law Number 9 of 1985 concerning Fisheries as amended by Law Number 31 of 2004, Law Number 7 of 1992 concerning Banking as amended by Act Number 10 of 1998, Law Number 8 of 1995 concerning Capital Markets, Law Number 10 of 1995 concerning Customs, Law Number 5 of 1997 concerning Psychotropics, Law Number 22 of 1997 concerning Narcotics, Law Number 23 of 1997 concerning Environmental Management, Law Number 5 of 1999 concerning Prohibition of Monopoly and Unfair Business Competition, Law Number 8 of 1999 concerning Consumer Protection, Law Number 31 of 1999 concerning Eradication of Corruption Crimes as amended by Law Number 20 of 2001, Law Number 15 of 2002 concerning Criminal Acts of Money Laundering as amended by Law Number 25 of $2003 .^{52}$

The formulation of corporate criminal responsibility is certainly not enough just to mention the corporation as the subject of a criminal act, but also must determine the rules regarding the criminal system and its penalties so that an effort is needed to reorient and reformulate criminal liability for victims of corporate crime in the future. Reorientation and reformulation of criminal liability for victims of corporate crimes, including the provisions regarding First, provisions regarding when a crime can be said to be a criminal offense committed by a corporation. Second, who can be prosecuted and convicted of crimes committed by corporations. Then, types of sanctions per the subject of a criminal offense in the form of a corporation oriented to granting compensation to the victim. Formulations regarding these provisions must be strictly regulated to minimize the possibility of corporations freeing themselves from

48 Anugerah Rizki Akbari, "Polemik Penyusunan Rancangan KUHP: Kesesatan Berfikir terhadap Konsep Kodifikasi, Prinsip Lex Specialis, dan Klasifikasi Tindak Pidana” (2014) l Fiat Masyarakat Pemantau Peradilan Indonesia FHUI.

49 Shinta Agustina, "Pengaturan Tindak Pidana Korupsi dalam Kerangka Pembaruan Hukum Pidana Indonesia” (2015) Review RUU KUHP dan Upaya Pemberantasan Korupsi ICW 2.

50 Barda Nawawi Arief, RUU KUHP Baru: Sebuah Restrukturisasi'Rekonstruksi Sistem Hukum Pidana Indonesia, Naskah Akademik RUU KUHP (Semarang: Pustaka Magister, 2007).

51 Barda Nawawi Arief, Masalah Penegakan Hukum dan Kebijakan Hukum Pidana dalam Penanggulangan Kejahatan, lst ed, 5 (Semarang: Prenadamedia Group, 2018).

52 Barda Nawawi Arief, Kapita Selekta Hukum Pidana (Bandung: Citra Aditya Bakti, 2003). 
responsibility for crimes committed. It is impossible to provide the fulfillment of compensation suffered by the victim by the corporation if the corporation in question cannot be charged, prosecuted, and convicted based on existing laws and regulations.

The concept of compensation payments in the form of compensation and restitution, as outlined in the form of legislation, has been developed for a long time in developed countries. Restitution is essentially a form of responsibility of the perpetrators of crimes, in this case, the corporation, for the benefits obtained in ways that violate the law and harming other parties (victims). The basis for applying restitution is that restitution itself is specifically for victims of crime or the return or restoration of losses arising after the occurrence of crime (real or actual victims). ${ }^{53}$

In the explanation of the draft of the Penal Code, it outlines: "the birth of this exception is the refinement and deepening of the moral basis of juridical regulative, namely in certain things one's responsibility is seen to be extended to acts of his subordinates who did the work or works for him or within the confines of his order. ${ }^{54}$ The principle of responsibility, which is an exception, is also known as the principle of absolute responsibility or "type liability." 55 In connection with the understanding of the corporation, the Criminal Code concept also regulates the corporation as the subject of criminal acts regulated in Article 47 of the Criminal Code concept. The Criminal Code concept also provides a corporate understanding in Article 182, namely: "Corporations are an organized collection of people and/or wealth, both legal entities and non-legal entities." By regulating corporations as subjects of criminal acts in the Criminal Code Concept, it is expected that these rules can become a guideline for the regulation of corporations as subjects of crime in legislation outside the Criminal Code. ${ }^{56}$ In the opinion of the author, the definition proposed in the Criminal Code concept is correct, but there needs to be further elaboration, especially related to organized organizations, where this understanding can also ensnare government institutions. ${ }^{57}$ For example, if it is related to fraud in the field of taxation, if this act does not have a systemic safeguard and has been carried out many times by its employees or even carried out systematically and known by its superiors, this condition subject to the perpetrators must be categorized as subjects of corporate crime. The aspect of organized crime, which in the literature has a place in its classification, but actually in a broader sense is a part of corporate crime; a corporation is an organization, a form of organization with a specific purpose that is engaged in economics or business, then we must look corporate crime as an organized crime, which is a crime that occurs in the context of complex relationships and expectations between the board of directors, executives and managers of one party and between the headquarters, divisions, and branches of the

53 Evan Elroy Situmorang, "Kebijakan Formulasi Pertanggungjawaban Pidana Korporasi Terhadap Korban Kejahatan Korporasi” J Law Reform 25.

54 Endi Arofa et al, "Corporate Criminal Liability for Corruption Offences in Indonesian Criminal Justice System” 3:8 Int J Adv Res (2015) 246-250.

55 Ibid.

56 Paulus Aluk Fajar D S, "Tinjauan Tentang Subjek Hukum Korporasi DanFormulasi Pertanggungjawaban Dalam Tindak Pidana” (2012) 3:2 Humaniora.

57 Ibid. 
other party. ${ }^{58}$ Based on the understanding as mentioned above, corporations are no longer only related to legal entities or business entities but also related to a form of organization, both private and government. ${ }^{59}$ So crime that occurs in the tax sector, in the field of labor, in the field of environment and other fields organized by government institutions can be held accountable up to the corporate level.

There are four patterns of punishment against corporations. First, the corporation is accused and prosecuted at trial, and the sentence is terminated after the management is first processed, and the conviction is decided to have permanent legal force (in kracht). Second, the corporation was made a defendant and prosecuted at trial, and the conviction was terminated without (preceded by) the conviction of its management. Third, the conviction for corporations is based on the demands of the public prosecutor without being named as a defendant. Then, finally, the conviction for corporations without being charged and prosecuted by the public prosecutor. The Supreme Court, through Decision Number 2239 K/PID.SUS/2012 overrides legal procedures (without establishing a corporation as a suspect and defendant) by passing a conviction verdict on a corporation without being charged and prosecuted by the public prosecutor. ${ }^{60}$

\section{CONCLUSION}

In Indonesia, the development of corporations as subject to criminal acts takes place outside the Criminal Code, in particular legislation. While the Criminal Code itself still adheres to the subject of criminal acts in the form of people. In its development, the corporation (juridical person) appears as a subject that can commit a crime and should also be accountable in criminal law, but unfortunately, this condition has not been realized concretely in our Criminal Code. Then there are several theories of corporate criminal liability on which to base criminal liability on corporations. The theory of corporate criminal liability includes the theory of identification (identification theory), vicarious liability theory, and the theory of absolute liability (strict liability).

The formulation policy regarding corporate criminal liability for victims of corporate crime that exists or is currently in force has not been able to realize the corporate criminal liability. Although there are sanctions that can be imposed on corporations, most of these provisions only protect potential victims and are not responsible for actual or real victims. In other words, the current formulation policy has not been able to ensnare and impose criminal sanctions on corporations who commit crimes, especially criminal sanctions which are oriented to the fulfillment or restoration of victims' rights in the form of compensation payments after the crime. This inability is caused by weaknesses contained in the formulation of corporate criminal liability for victims of corporate crime, which include: the lack of uniformity in determining when a

58 Ibid at 429.

59 Ibid.

60 Budi Suhariyanto, "Putusan Pemidanaan Terhadap Korporasi Tanpa Didakwakan Dalam Perspektif Vicarious Liability" (2017) 10 Journal Yustisia 27. 
corporation can be said to have committed a crime, the lack of uniformity in the arrangements regarding who can be accounted for or prosecuted and convicted criminal, as well as formulations of types of crimes that can be imposed on corporations that commit criminal acts. Reorientation and reformulation of criminal liability for victims of corporate crimes are needed, including the provisions regarding: First, provisions regarding when a crime can be said to be a criminal offense committed by a corporation. Second, who can be prosecuted and convicted of crimes committed by corporations. Then, types of sanctions per the subject of a criminal offense in the form of a corporation oriented to granting compensation to the victim. Formulations regarding these provisions must be strictly regulated to minimize the possibility of corporations freeing themselves from responsibility for crimes committed. It is impossible to provide the fulfillment of compensation suffered by the victim by the corporation if the corporation in question cannot be charged, prosecuted, and convicted based on existing laws and regulations.

\section{ACKNOWLEDGMENTS}

None.

\section{COMPETING INTERESTS}

The authors declare that they have no competing interests.

\section{REFERENCES}

Kholiq, Abdul. Hukum Pidana (Yogyakarta: Fakultas Hukum Universitas Islam Indonesia, 2002).

Muladi \& Diah. Pertanggungjawaban Pidana Korporasi/Corporate Criminal Responsibility, 2d ed (Bandung: PT. Alumni, 2015).

Muladi \& Dwija Priyatna. Pertanggungjawaban Korporasi Dalam Hukum Pidana (Bandung: Penerbit Sekolah Tinggi Hukum Bandung, 1991).

Nawawi Arief, Barda. Kapita Selekta Hukum Pidana (Bandung: Citra Aditya Bakti, 2003).

- - . Kebijakan Legeslatif Dalam Penenggulangan Kejahatan Dengan Pidana Penjara (Dissertation, Diponegoro University, 1994) [unpublished].

- - Masalah Penegakan Hukum dan Kebijakan Hukum Pidana dalam Penanggulangan Kejahatan, lst ed, 5 (Semarang: Prenadamedia Group, 2018).

- - . RUU KUHP Baru: Sebuah Restrukturisasi'Rekonstruksi Sistem Hukum Pidana Indonesia, Naskah Akademik RUU KUHP (Semarang: Pustaka Magister, 2007).

Prasetyo, Teguh \& Abdul Halim Barkatullah. Politik Hukum Pidana, Ctk. Pertama (Yogyakarta: Pustaka Pelajar, 2005).

Reksodiputro, Mardjono. Tindak Pidana Korporasi dan Pertanggungjawabanya (Perubahan Wajah Pelaku Kejahatan di Indonesia) (Yogyakarta: FH UGM, 2014). 
S Hulukati, Kartin. Kebijakan Formulasi Tindak Pidana Ekonomi Dengan Undang-Undang Nomor 7/DRT/1955 (Semarang: Badan Penerbit Universitas Diponegoro, 2003).

Serikat Putra, Nyoman. Hukum dan Hukum Pidana di Bidang Ekonomi (Semarang: Badan Penerbit Universitas Diponegoro, 2018).

Van Bemmelen, JM. Hukum Pidana I: Hukum Pidana Material Bagian Umum (Bandung: Binacipta, 1986).

Agustina, Shinta. "Pengaturan Tindak Pidana Korupsi dalam Kerangka Pembaruan Hukum Pidana Indonesia" (2015) Review RUU KUHP dan Upaya Pemberantasan Korupsi ICW 2.

Ali Reza, Aulia. "Pertanggungjawaban Korporasi Dalam Rancangan Kitab UndangUndang Hukum Pidana” (2015) ICJR 4.

Aluk Fajar D S, Paulus. "Tinjauan Tentang Subjek Hukum Korporasi DanFormulasi Pertanggungjawaban Dalam Tindak Pidana” (2012) 3:2 Humaniora.

Arofa, Endi et al. "Corporate Criminal Liability for Corruption Offences in Indonesian Criminal Justice System” 3:8 Int J Adv Res (2015) 246-250.

- _ - "Korporasi Sebagai Subjek Dan Bentuk Pemidanaannya Dalam Tindak Pidana Korupsi” (2018) 5:1 J Surya Kencana 2449.

Card, Richard. "Reformasi Pertanggungjawaban Pidana” (1999) 6:11 J Ilmu Huk 29.

Chasani, Muchammad. "Corporate Criminal Liability In Indonesia On The Perspective Of Comparison” (2017) II:2 IJCLS 149.

Elroy Situmorang, Evan. "Kebijakan Formulasi Pertanggungjawaban Pidana Korporasi Terhadap Korban Kejahatan Korporasi” J Law Reform 25.

Haryanto, M. "Pertanggungjawaban Pidana Korproasi dan Individualisasi Pidana" (2012) 2 J Refleksi Huk 203.

Keulen, BF \& E Gritter. "Corporate Criminal Liability in the Netherlands" 14:3 Electron J Comp Law 5.

Krismen, Yudi. "Pertanggungjawaban Pidana Korporasi dalam Kejahatan Ekonomi" (2014) 0403 June 2014 (1) 140.

Kristian. "Urgensi Pertanggungjawaban Pidana Korporasi” (2014) Year-43:Hukum dan Pembangunan Oct-Dec (04) 550.

Priyanto, Dwidja. "Reorientasi dan Reformulasi Sistem Pertanggungjawaban Pidana Korporasi dalam Kebijakan Kriminal dan Kebijakan Hukum Pidana” (2007) 9:3 Syiar Huk 205.

Rangkuti, Ridwan. "Pertanggungjawaban Korporasi terhadap Tindak Pidana Lingkungan Hidup Menurut Undang-Undang Nomor 23 Tahun 1997" (2014) 1:3 J Yust 263.

Rinwigati, Patricia. "Tindak Pidana Ekonomi Dalam RKUHP: Quo Vadis?” (2016) Parliamentary Brief Aliansi Nas Reformasi KUHP (6) 5.

Rizki Akbari, Anugerah. "Polemik Penyusunan Rancangan KUHP: Kesesatan Berfikir terhadap Konsep Kodifikasi, Prinsip Lex Specialis, dan Klasifikasi Tindak Pidana" (2014) l Fiat Masy Pemantau Peradil Indones FHUI (2) . 
36 | Theoretical and Conceptual Reflection Regarding Corporate Criminal Responsibilities...

Sridjaja Pradjonggo, Tjandra. "Alternatif Sanksi Pidana dalam Kejahatan Korporasi" (2010) 80:2 J Yust 70.

Suhariyanto, Budi. "Putusan Pemidanaan Terhadap Korporasi Tanpa Didakwakan Dalam Perspektif Vicarious Liability” (2017) 10 J Yust 27-28.

- - - "The Role Of Regulation Of The Supreme Court Number 13 Year 2016 In Overcoming The Obstacles Of Corporation Criminal Infringement" (2018) Peneliti Huk MA 103.

- - - "Urgensi Pemidanaan terhadap Pengendali Korporasi yang Tidak Tercantum dalam Kepengurusan" (2017) 103 Yudisial 240.

Sunarto. "Pertanggungjawaban Pidana Korporasi Dalam Tindak Pidana Korupsi" UNTAG Semarang 48.

United Nations. "Guiding Principles for Crime Prevention and Criminal Justice in the Context of Development and a New International Economic Order" 4.

W Edgerton, Henry. "Corporate Criminale Responsibility” 36:6 Yale Law J 882.

Yustitianingtyas, Levina. "Pertanggungjawaban Pidana oleh Korporasi dalam Tindakan Pelanggaran HAM di Indonesia” (2016) 7:1 Novelty 25.

Rahardian, Taufik. "Kelemahan 8 PERMA Pidana Korporasi", online: Kumparan News 〈https://kumparan.com/@kumparannews/8-kekurangan-perma-pidanakorporasi>.

Peraturan Mahkamah Agung Republik Indonesia Nomor 13 Tahun 2016 Tentang Tata Cara Penanganan Perkara Tindak Pidana Oleh Korporasi. 